\title{
TINGKAT PENGETAHUAN PASIEN TENTANG PERAWATAN LUKA DIABETES MELITUS DI RUMAH SAKIT PTPN II BANGKATAN BINJAI TAHUN 2016
}

\author{
Level of Knowledge of Patients on Diabetes Melitus Treatment In PTPN II \\ Bangkatan Binjai Hospital in 2016
}

\author{
Leli Herawati ${ }^{1}$ \\ ${ }^{1}$ Dosen Akademi Keperawatan Sehat Binjai \\ E-mail: leli.herawati0987@gmail.com
}

\begin{abstract}
Abstrak
Luka Diabetik adalah luka yang terjadi pada pasien dengan diabetik yang melibatkan gangguan pada saraf pariferal dan autonomik. Setiap tahun lebih dari satu juta orang penderita Diabetes kehilangan salah satu kakinya sebagai salah satu komplikasi Diabetes, ini berarti bahwa setiap 30 detik satu tungkai hilang karena Diabetes di suatu tempat di dunia. Tujuan penelitian ini adalah untuk mengetahui tingkat pengetahuan pasien dalam perawatan luka Diabetes Melitus di Rumah Sakit PTPN II Bangkatan Binjai Tahun 2016. Metode penelitian ini bersifat observasional deskriptif. Populasi dalam penelitian ini adalah seluruh pasien yang dirawat di Ruang Wanita RS PTPN II Bangkatan Binjai, berjumlah 20 orang. Sampel dalam penelitian ini berjumlah 10 orang dengan tekhnik pengambilan sampel Accidental Sampling. Hasil penelitian ini menunjukkan bahwa Tingkat Pengetahuan Pasien Tentang Perawatan Luka Diabetes di Ruang Wanita Rumah Sakit PTPN II Bangkatan Binjai Tahun 2016 yang di interprestasikan terdapat yang berpengetahuan baik sebanyak 6 orang (60\%), cukup sebanyak 2 orang (20\%) dan kurang sebanyak 2 orang (20\%). 3. Diharapkan pasien mampu mencegah Luka Diabetes dengan pengendalian glukosa darah, penggunaan alas kaki, merawat kuku kaki, perawatan kaki dan senam kaki. Jika sudah terjadi Komplikasi dengan Luka Diabetes, diharapkan pasien mampu melakukan perawatan luka diabetes dengan baik.
\end{abstract}

Kata Kunci: Pengetahuan Pasien, Perawatan Luka Diabetes Melitus

\begin{abstract}
Diabetic wounds are injuries that occur in patients with diabetics involving disorders of the peripheral and autonomic nerves. Every year more than one million people with diabetes lose one of their legs as one of the complications of diabetes, this means that every 30 seconds one leg is lost due to diabetes somewhere in the world. The purpose of this study was to determine the level of knowledge of patients in the treatment of diabetes mellitus wounds in PTPN II Hospital Binjai Departure in 2016. The method of this study was descriptive observational. The population in this study were all patients treated at the Women's Room at PTPN II Bangkat Binjai Hospital, totaling 20 people. The sample in this study amounted to 10 people with accidental sampling techniques. The results of this study indicate that the Knowledge Level of Patients About Diabetes Wound Care in the Women's Room of PTPN II Hospital Binjai Departure in 2016 which is interpreted is good knowledge as many as 6 people (60\%), enough as many as 2 people (20\%) and less than 2 people (20\%). 3. It is expected that patients will be able to prevent Diabetes Injuries by controlling blood glucose, using footwear, treating toenails, foot care and foot exercises. If Complications with Diabetes Injuries have occurred, the patient is expected to be able to treat diabetic wounds properly.
\end{abstract}

Keywords: Patient Knowledge, Diabetes Melitus Wound Care

\section{PENDAHULUAN}

Diabetes Mellitus (DM) adalah penyakit kronis yang terjadi ketika tubuh tidak dapat memproduksi cukup insulin atau menggunakan insulin secara efektif. Menurut American Diabetes Asociation (ADA), DM dapat diklasifikasikan menjadi beberapa tipe yakni, DM tipe 1 ,
DM tipe 2, DM Gestasional dan DM tipe lain. Beberapa tipe yang ada, DM tipe 2 merupakan salah satu jenis yang paling banyak di temukan yaitu lebih dari $90-95 \%$ (ADA, 2015).

Diabetes melitus (DM) menyebabkan angka kesakitan dan kematian yang terus meningkat diseluruh dunia. 
Menurut WHO angaka prevalensi DM telah mencapai jumlah wabah atau Epidemi, WHO memperkirakan pada negara berkembang pada tahun 2025 akan muncul $80 \%$ kasus baru. Saat ini DM di tingkat dunia di perkirakan lebih dari 230 juta, hampir mencapai proposi B\% dari populasi orang dewasa. Di perkirakan 20 tahun mendatang jumlah penderita DM akan mencapai 350 juta. Setiap 10 detik ada orang yang meninggal terkait dengan DM. DM merupakaan penyakit Epidemi tersembunyi yang memakan korban setiap tahunnya. DM tipe 2 adalah penyakit yang di sebabkan oleh faktor genetik 'dan lingkungan, yang biasanya muncul saat usia dewasa. DM tipe 2 bertanggung jawab atas 90-95\% kasus DM, Amputasi sampai 1 dan bertanggung jawab terhadap tingginya angka biaya hemodialisis.

Pada saat ini, terjadi peningkatan prevalensi DM di seluruh dunia. Pada tahun 2013, tercatat sebesar 382 juta orang di dunia yang berumur 40-59 tahun menderita DM dan diperkirakan akan terus meningkat setiap tahunnya. Data regional IDF menunjukkan bahwa Asia Tenggara menduduki peringkat ke-2 tertinggi di dunia dengan jumlah penderita DM sebanyak 72 juta jiwa. Pada tahun 2035 diperkirakan angka ini akan meningkat $70.6 \%$ menjadi 122,8 juta penderita (IDF, 2013).

Jumlah penderita DM di Indonesia menduduki peringkat ke-7 dunia (IDF, 2013). Saat ini prevalensi DM di Indonesia yang telah didiagnosis dokter adalah $1,4 \%$, jumlah ini diperkirakan akan terus meningkat (Riskesdas, 2013).

RISKESDES (2013) menambahkan bahwa peningkatan tersebut terjadi sesuai dengan bertambahnya umur, namun mulai umur 65 tahun cenderung menurun, cenderung lebih tinggi perempuan dari pada laki-laki, dan lebih tinggi diperkotaan dari pada dipedesaan. Federasi Internasional menyatakan insiden tersebut secara tidak langsung meningkatkan prevalensi luka DM $1,4 \%$ (Saad, 2013).

Berdasarkan Hasil Riset Kesehatan Dasar (2007), angka prevalensi tertinggi terdapat di Provinsi Kalimantan Barat dan Maluku Utara (masing-masing 11,1\%), diikuti Riau (10,4\%), dan NAD (8,5\%). Sementara itu Prevalensi Diabetes Melitus terendah ada di Provinsi Papua (1,7\%), diikuti NTT (1,8\%). Prevalensi glukosa terganggu tertinggi di Papua Barat $(21,8 \%)$, diikuti Sulawesi Barat $(17,6 \%)$ dan Sulawesi Utara $(17,3 \%)$ sedangkan terendah di Jambi (4\%). DM terbanyak pada kelompok usia 45-54 tahun, di daerah perkotaan sebesar $14,7 \%$ sedangkan didaerah pedesaan $5,8 \%$.

Peningkatan prevalensi DM juga terjadi di provinsi Sumatera Utara. Prevalensi penderita DM di Sumatera Utara pada tahun 2012 adalah 1,8\% (Riskesdas, 2013). Penanganan Diabetes yang tidak baik menyebabkan peningkatan luka DM, dimana beresiko terjadinya kerusakan syaraf, yang menuju kepada kerusakan aliran darah dan menyebabkan mati rasa pada kaki. Hal ini menambah kerentanan terhadap luka-luka di kaki yang memerlukan waktu lama untuk disembuhkan dan bahaya infeksi (Rowe, 2014).

Luka Diabetes adalah komplikasi Diabetes yang membutuhkan perawatan optimal di Rumah Sakit akibat ulkus, infeksi dan gangren yang menyebabkan beban biaya yang berat bagi pasien dan keluarga serta pasien dapat mengalami amputasi (Rowe, 2014). Setiap tahun lebih dari satu juta orang penderita Diabetes kehilangan salah satu kakinya sebagai salah satu komplikasi Diabetes, ini berarti bahwa setiap 30 detik satu tungkai hilang karena Diabetes di suatu tempat di dunia. Dari semua amputasi tungkai bawah $40-70 \%$ berkaitaan dengan Diabetes banyak insiden amputasi tungkai bawah di perkirakan 5-25/100,000 orang/tahun sedangkan penderita Diabetes jumlah penderita yang di amputasi sebanyak 6-8/1000 orang mayoritas amputasi ini di dahului ulkus (Soegondo, 2013).

Menurut pakar Dabetes Em Yunir, di Indonesia ulkus diabetes merupakan kasus yang paling banyak dirawat dirumah sakit. Angka kematian yang disebabkan oleh ulkus Diabetes berkisar sebayak 17-23\% sedangkan angka amputasi sebanyak 15$30 \%$ (Pdpersi, 2011). Pakar Biokimia dan Biomedis Australia menyatakan Indonesia memiliki populasi penderita Diabetes terbesar keempat didunia dan radang kaki Dabetes (Diabetic Foot Ulcer) menjangkit 
hampir 45\% dari seluruh amputasi Diabetes (Kedutaan Besar Australia Indonesia, 2013).

Komplikasi Luka Diabetic seperti kejadian ulkus merupakan penyebab tersering amputasi berdasarkan kejadian non-traumatik. Resiko amputasi 15-40 kali lebih sering pada pasien DM dibandingkan non-DM. Menurut saad (2013) strategi pengolaan untuk merawat luka diabetes adalah dengan mencegah tekanan dan kaki jatuh kedepan. Penerapan kerangka kerja dalam perawatan luka diabetic dikenal dengan (tissue management. Inflamasi, infection control, moisture balance, and epithelial (edge) advancement). Selain itu selalu memonitor kadar gula darah pasien dan memperhatikan penyebab yang dapat menyebabkan trauma minor pada kaki yang tidak terlihat seperti pembentukan kallus akibat menggunakan alas kaki yang tidak sesuai (Holt, 2013).

Keluarga memiliki peranan yang sangat penting bagi pasien diabetes. Perilaku pengelolaan perawatan luka penyakit DM oleh pasien perlu dilakukan terus-menerus dan dibutuhkan adanya peran serta keluarga untuk memberikan dukungan agar pasien termotivasi melakukannya. Dukungan keluarga merupakan faktor yang paling utama untuk mempertahankan metabolik kontrol yang akan mempengaruhi kualitas hidup pasien. Sehingga pasien dan keluarga perlu memiliki pengetahuan tentang perawatan luka Diabetik.

\section{METODE}

Penelitian ini bersifat observasional deskriptif di lakukan terhadap sekumpulan objek yang biasanya bertujuan untuk melihat gambaran fenomena (termasuk kesehatan) yang terjadi di dalam suatu populasi tertentu. Penelitian ini menggambarkan tingkat pengetahuan pasien tentang perawatan luka Diabetik di Rumah Sakit PTPN II Bangkatan Binjai Tahun 2016.

Lokasi penelitian ini dilakukan di RS PTPN II Bangkatan Binjai dengan alasan: tersedianya responden, hemat waktu dan biaya, dan lokasi yang dekat

Penelitian ini dilakukan pada Bulan Januari 2016 dalam kurun waktu tersebut dilakukan survey lapangan, penelusuran pustaka, pengajuan judul, bimbingan proposal, seminar proposal, survey penelitian, pembagian quisioner, bimbingan KTI dan seminar KTI.

Populasi adalah seluruh subjek atau objek dengan karakteristik tertentu yang akan diteliti (Hidayat, 2007). Populasi dalam penelitian ini adalah seluruh pasien yang dirawat di Ruang Wanita RS PTPN II Bangkatan Binjai, berjumlah 20 orang

Sampel merupakan bagian populasi yang akan diteliti atau sebagian dari jumlah dari karakteristik yang dimiliki oleh populasi (Notoatmodjo, 2011).

Sampel dalam penelitian ini adalah seluruh pasien yang berada di Ruang Wanita RS PTPN II Bangkatan Binjai Tahun 2016. Tekhnik sampling yang digunakan dalam penelitian ini adalah accidental sampling karena dilakukan dengan mengambil kasus atau responden yang kebetulan ada atau tersedia disuatu tempat sesuai dengan konteks penelitian. Populasi dijadikan sampel berjumlah 10 orang (Notoatmodjo, 2011).

Sebelum melakukan pengumpulan data, perlu dilihat alat ukur pengumpulan data agar dapat memperkuat hasil penelitian. Alat ukur pengumpulan data tersbut berupa kuesioner/angket, observasi, wawancara atau gabungan ketiganya (Hidayat, 2012).

Cara pengumpulan data pada penelitian ini adalah menggunakan kuesioner. Dalam penelitian ini penulis menjelaskan kepada responden tentang tujuan, manfaat dan proses pengisian kuesioner sebelum menyatakan kesediaan menjadi responden. Calon responden yang bersedia diminta untuk menandatangani lembar persetujuan yang telah disediakan, responden diberikan kuesioner yang akan diisi dan selanjutnya data dikumpulkan untuk dianalisa.

Dalam penelitian ini menggunakan skala Guttman sebagai alat ukur data, skala Guttman merupakan skala yang bersifat tegas seperti jawaban dan pertanyaan ya dan tidak, tahu dan tidak tahu. Tujuan meggunakan skala ini untuk memudahkan responden dalam pengisisan kuesioner. (Hidayat, 2007).

Untuk mengukur pengetahuan responden tentang perawatan Luka Diabetes dengan menggunakan pertanyaan skala 
Guttman sebanyak 20 pertanyaan, sebagai berikut:

1. Definisi Tentang Perawatan Luka

Diabetes Melitus (no 1-5)

2. Pencegahan Perawatan Luka Diabetes

Melitus (no 6-10)

3. Tujuan Perawatan Luka Diabetes

Melitus (no 10-15)

Analisa data dalam penelitian ini 1. Analisis Univarite (Analsis deskriptif)

Analisis univariat bertujuan untuk menjelaskan atau mendeskripsikan karakteristik setiap variabel penelitian. Untuk data numerik digunakan nilai mean rata - rata, median standar deviasi. Misalnya, distribusi frekuensi responden berdasarkan : umur, jenis keamin, tingkat pendidikan,dan sebagainya.

$\mathrm{P}=\mathrm{F} / \mathrm{N} \mathrm{X} 100 \%$

Keterangan:

$\mathrm{P}=$ Persentase

$\sum \mathrm{F}=$ Jumlah jawaban yang benar

$\mathrm{N}$ = Jumlah pertanyaan

Setelah mendapatkan perhitungan data sebelumnya, nilai - nilai :

a. Kategori baik adalah apabila pertanyaan benar responden $76 \%-100 \%$

b. Kategori cukup adalah apabila pertanyaan benar oleh responden $60 \%$ $75 \%$

c. Kategori kurang adalah apabila pertanyaan benar oleh responden $\leq$ $59 \%$.

\section{HASIL PENELITIAN}

\section{Karakteristik Responden}

Pelaksanaan penelitian Tingkat Pengetahuan Pasien tentang Perawatan Luka Daibetes di Ruang Wanita Rumah Sakit PTPN II Bangkatan Binjai Tahun 2016 yang dilakukan pada bulan Januari sampai dengan April 2016. Sampel dalam penelitian adalah Pasien Diabetes Melitus di Ruang Wanita Rumah Sakit PTPN II Bangkatan dengan jumlah sampel 10 orang. Setelah mendapat penjelasan dari peneliti maka responden diberikan pertanyaan secara tertutup yang disebarkan seluruhnya.

Berdasarkan quesioner yang telah dikembalikan, diperoleh data-data mentah yang perlu diolah, hasil penelitian berdasarkan Tingkat Pengetahuan Pasien tentang Perawatan Luka Diabetes di Rumah
Sakit PTPN II Bangkatan Binjai data-data tersebut ditabulasi dan dipersentasikan pada masing-masing tim, kemudian diinterprestasikan sesuai dengan variabel dan diketahui beberapa hal yang berkaitan dengan penelitian yang telah dilakukan.

\section{Distribusi Data Umum Responden}

Tabel 1. Distribusi Tingkat Pengetahuan Responden Tentang Perawatan Luka Diabetes Berdasarkan Umur Di Ruang Bersalin Rumah Sakit PTPN II Bangkatan Binjai Tahun 2016

\begin{tabular}{|c|c|c|c|}
\hline No & Umur & Frekuensi & Persentase \\
\hline 1 & $30-40$ & 2 & $20 \%$ \\
\hline 2 & $41-50$ & 5 & $50 \%$ \\
\hline \multirow[t]{2}{*}{3} & $51-60$ & 3 & $30 \%$ \\
\hline & Jumlah & 10 & $100 \%$ \\
\hline & $\begin{array}{l}\text { Berdasar } \\
\text { ui bahw } \\
\text { aden terd } \\
\text { sebanyak }\end{array}$ & $\begin{array}{l}\text { abel } 1 \mathrm{~d} \\
\text { mayoritas } \\
\text { orang }(50 \% \\
\text { ora usi }\end{array}$ & $\begin{array}{l}\text { atas dapat di } \\
\text { rentang usia } \\
41-50 \text { tahun }\end{array}$ \\
\hline
\end{tabular}

Tabel 2. Distribusi Tingkat Pengetahuan Responden Tentang Perawatan Luka Diabetes Berdasarkan Tingkat Pendidikan Di Ruang Bersalin Rumah Sakit PTPN II Bangkatan Binjai Tahun 2016

\begin{tabular}{cccc}
\hline No & $\begin{array}{c}\text { Pendidi- } \\
\text { kan }\end{array}$ & Frekuensi & Persentase \\
\hline 1 & SMP & 7 Org & $70 \%$ \\
2 & SMA & 3 Org & $30 \%$ \\
3 & S1 & 0 Org & $0 \%$ \\
& & & \\
\hline & Jumlah & $\mathbf{1 0 ~ O r g}$ & $\mathbf{1 0 0 \%}$ \\
\hline
\end{tabular}

Berdasarkan Tabel 2 di atas dapat di ketahui bahwa mayoritas pendidikan responden berpendidikan SMP yaitu sebanyak 7 orang $(70 \%)$.

Tabel 3. Distribusi Tingkat Pengetahuan Responden Tentang Perawatan Luka Diabetes Berdasarkan Pekerjaan Di Ruang Wanita Rumah Sakit PTPN II Bangkatan Binjai Tahun 2016 


\begin{tabular}{clcc}
\hline No & $\begin{array}{c}\text { Pendi- } \\
\text { dikan }\end{array}$ & $\begin{array}{c}\text { Freku- } \\
\text { ensi }\end{array}$ & $\begin{array}{c}\text { Persen- } \\
\text { tase }\end{array}$ \\
\hline 1 & IRT & 4 & $40 \%$ \\
2 & PNS & 0 & $0 \%$ \\
3 & Wiraswasta & 2 & $20 \%$ \\
4 & Petani & 4 & $40 \%$ \\
\hline & Jumlah & $\mathbf{1 0}$ & $\mathbf{1 0 0 \%}$ \\
\hline
\end{tabular}

Berdasarkan tabel 3 di atas dapat di ketahui bahwa mayoritas pekerjaan responden yaitu bekerja sebagai IRT dan petani, IRT sebanyak 4 orang $(40 \%)$ dan Petani 4 orang $(40 \%)$.

\section{Distribusi Tingkat Pengetahuan Responden}

Tabel 4. Distribusi Tingkat Pengetahuan Responden Tentang Perawatan Luka Diabetes Berdasarkan Definisi Luka Diabetes di Ruang Wanita Rumah Sakit PTPN II Bangkatan Binjai Tahun 2016

\begin{tabular}{cccc}
\hline No & $\begin{array}{c}\text { Definisi } \\
\text { Luka } \\
\text { Diabetes }\end{array}$ & $\begin{array}{c}\text { Freku- } \\
\text { ensi }\end{array}$ & $\begin{array}{c}\text { Persen- } \\
\text { tase }\end{array}$ \\
\hline 1 & Baik & 6 & $60 \%$ \\
2 & Cukup & 2 & $20 \%$ \\
3 & Kurang & 2 & $20 \%$ \\
\hline & Jumlah & $\mathbf{1 0}$ & $\mathbf{1 0 0 \%}$ \\
\hline
\end{tabular}

Berdasarkan Tabel 4 di atas dapat di ketahui bahwa dari 10 responden $(100 \%)$ yang berpengetahuan baik tentang Definisi Luka Diabetes di Ruang Wanita Rumah Sakit PTPN II Bangkatan Binjai adalah sebanyak 6 orang $(60 \%)$, berpengetahuan cukup 2 orang (20\%) dan berpengetahuan kurang 2 orang $(20 \%)$.

Tabel 5. Distribusi Tingkat Pengetahuan Responden Tentang Perawatan Luka Diabetes Berdasarkan Pencegahan Luka Diabetes di Ruang Wanita Rumah Sakit PTPN II Bangkatan Binjai Tahun 2016

\begin{tabular}{lccc}
\hline No & $\begin{array}{c}\text { Pencegahan } \\
\text { Luka } \\
\text { Diabetes }\end{array}$ & $\begin{array}{c}\text { Freku- } \\
\text { ensi }\end{array}$ & $\begin{array}{c}\text { Persen- } \\
\text { tase }\end{array}$ \\
\hline 1 & Baik & 5 & $50 \%$ \\
2 & Cukup & 4 & $40 \%$ \\
\hline
\end{tabular}

\begin{tabular}{cccc}
\hline 3 & Kurang & 1 & $10 \%$ \\
\hline & Jumlah & $\mathbf{1 0}$ & $\mathbf{1 0 0 \%}$ \\
\hline
\end{tabular}

Berdasarkan Tabel 1.5 diatas dapat di ketahui bahwa dari 10 responden (100\%) yang berpengetahuan baik tentang Pencegahan Luka Diabetes di Ruang Wanita Rumah Sakit PTPN II Bangkatan Binjai adalah sebanyak 5 orang (50\%), berpengetahuan cukup 4 orang $(40 \%)$ dan berpengetahuan kurang 1 orang (10\%).

Tabel 6. Distribusi Tingkat Pengetahuan Responden Tentang Perawatan Luka Berdasarkan Tujuan Perawatan Luka Diabetes di Ruang Wanita Rumah Sakit PTPN II Bangkatan Binjai Tahun 2016

\begin{tabular}{cccc}
\hline No & $\begin{array}{c}\text { Tujuan } \\
\text { Perawatan } \\
\text { Luka } \\
\text { Diabetes }\end{array}$ & $\begin{array}{c}\text { Freku } \\
\text { ensi }\end{array}$ & $\begin{array}{c}\text { Persen- } \\
\text { tase }\end{array}$ \\
\hline 1 & Baik & 5 & $50 \%$ \\
2 & Cukup & 4 & $40 \%$ \\
3 & Kurang & 1 & $10 \%$ \\
\hline & Jumlah & $\mathbf{1 0}$ & $\mathbf{1 0 0 \%}$ \\
\hline
\end{tabular}

Berdasarkan Tabel 6 di atas dapat di ketahui bahwa dari 10 responden $(100 \%)$ yang berpengetahuan baik tentang Tujuan Perawatan Luka Diabetes di Ruang Wanita Rumah Sakit PTPN II Bangkatan Binjai adalah sebanyak 5 orang $(50 \%)$, berpengetahuan cukup 4 orang $(40 \%)$ dan berpengetahuan kurang 1 orang (10\%).

Tabel 7. Distribusi Tingkat Pengetahuan Responden Tentang Perawatan Luka Diabetes di Ruang Wanita Rumah Sakit PTPN II Bangkatan Binjai Tahun 2016

\begin{tabular}{cccc}
\hline No & $\begin{array}{c}\text { Pengeta- } \\
\text { huan }\end{array}$ & $\begin{array}{c}\text { Freku- } \\
\text { ensi }\end{array}$ & $\begin{array}{c}\text { Persen- } \\
\text { tase }\end{array}$ \\
\hline 1 & Baik & 6 & $60 \%$ \\
2 & Cukup & 2 & $20 \%$ \\
3 & Kurang & 2 & $20 \%$ \\
\hline & Jumlah & $\mathbf{1 0}$ & $\mathbf{1 0 0 \%}$ \\
\hline
\end{tabular}

Berdasarkan hasil Tingkat Pengetahuan Pasien Tentang Perawatan Luka Diabetes di Ruang Wanita Rumah Sakit PTPN II Bangkatan Binjai Tahun 2016 
yang di interprestasikan terdapat yang berpengetahuan baik sebanyak 6 orang (60\%), cukup sebanyak 2 orang (20\%) dan kurang sebanyak 2 orang (20\%).

\section{PEMBAHASAN}

Dalam pembahasan ini penulis ingin membahas hal-hal yang berkaitan dengan penelitian seperti yang telah di kemukakan pada bagian pendahuluan bahwa tujuan umum adalah untuk mengetahui Tingkat Pengetahuan Pasien tentang Perwatan Luka Diabetes di Ruang Wanita Rumah Sakit PTPN II Bangkatan Binjai Tahun 2016.

\subsubsection{Karakteristik Umum Responden Penelitian}

1) Umur

Dari Tabel 1.1 dapat dilihat bahwa karakteristik responden penelitian berdasarkan usia di Ruang Wanita Rumah Sakit PTPN II Bangkatan Binjai Tahun 2016 terbanyak pada usia 41-50 tahun sebanyak 5 orang (50\%), 51-60 tahun sebanyak 3 orang (30\%), dan paling sedikit 30-40 tahun sebanyak 2 orang (20\%).

Berdasarkan data yang diperoleh peneliti mayoritas rentang usia reponden terdapat pada usia 41-50 tahun yaitu sebanyak 5 orang (50\%). Hasil penelitian ini sesuai dengan pendapat Notoadmodjo (2007) bahwa usia merupakan komponen yang berpengaruh dengan pengalamanpengalaman dan kemampuan berfikir. Umur berbanding lurus dengan pengetahuan dan pengalaman berarti semakin bertambah umur bertambah pengalaman dan pengetahuan. Hal ini dibuktikan dari hasil penelitian ini bahwa sebagian besar responden yang memiliki tingkat pengetahuan baik pada rentang usia $>40$ tahun yaitu sebanyak 5 orang (50\%), sedangkan yang paling sedikit pada rentang usia 30-40 tahun yaitu sebanyak 20 orang $(20 \%)$.

2) Pendidikan

Dari Tabel 1.2 dapat dilihat bahwa karakteristik responden penelitian berdasarkan pendidikan di Ruang Wanita Rumah Sakit PTPN II Bangkatan Binjai Tahun 2016 terbanyak berpendidikan SMP 7 orang (70\%) dan SMA 3 orang (30\%).
Berdasarkan jenjang pendidikan dalam penelitian ini bahwa responden yang paling banyak memiliki tingkat pengetahuan baik yaitu pada jenjang pendidikan SMA. Sedangkan yang paling sedikit pada jenjang pendidikan SMP.

Hasil penelitian tersebut sesuai dengan pendapat Hidayat (2008) pendidikan merupakan penuntut manusia untuk berbuat dan mengisi kehidupannya dapat digunakan sebagaimana umumnya semakin tinggi pendidikan sesorang semakin mudah menerima informasi dan semakin baik pengetahuan yang diketahui.

3) Pekerjaan

Dari Tabel 1.3 dapat dilihat bahwa karakteristik responden penelitian berdasarkan pekerjaan di Ruang Wanita Rumah Sakit PTPN II Bangkatan Binjai Tahun 2016 terbanyak bekerja sebagai IRT dan Petani yaitu IRT 4 orang (40\%), petani 4 orang $(40 \%)$ dan wiraswasta 2 orang $(20 \%)$.

Diketahui bahwa pekerjaan mempengaruhi tingkat pengetahuan sesorang. Berdasarkan jenis pekerjaan dalam penelitian ini bahwa responden yang paling banyak memiliki tingkat pengetahuan baik yaitu responden yang memiliki pekerjaan sebagai Petani sedangkan yang paling sedikit yaitu responden yang memiliki pekerjaan sebagai Wiraswasta dan Ibu Rumah Tangga (IRT).

Hasil penelitian ini sesuai dengan pendapat Notoadmodjo (2007) pekerjaan merupakan suatu cara mendapatkan hasil didalam suatu kebutuhan atau model kehidupan dalam rumah tangga, kesehatan kerja apalagi dalam kesehatan masyarakat ciri pokoknya adalah upaya preventif (pencegahan penyakit) dan promotif (promosi kesehatan) kemampuan seseorang dalam melakukan pekerjaan disamping itu kapasitas juga dipengaruhi oleh pendidikan, pengalaman, kesehatan, jenis kelamin dan ukuran tubuh.

\section{Pengetahuan Responden Tentang Perawatan Luka Diabetes, Definisi Luka Diabetes, Pencegahan Luka Diabetes dan Tujuan Perawatan Luka Diabetes}

1) Pengetahuan

Dari Tabel 4.7 berdasarkan hasil penelitian dapat disimpulkan bahwa tingkat 
pengetahuan keseluruhan Pasien tentang Perawatan Luka Diabetes di Ruang Wanita Rumah Sakit PTPN II Bangkatan Binjai Tahun 2016 berpengetahuan baik sebanyak 6 orang (60\%), berpengetahuan cukup 2 orang $(20 \%)$ dan berpengetahuan kurang 2 orang (20\%).

2) Definisi Luka Diabetes

Berdasarkan Tabel 1.4 berdasarkan hasil penelitian dapat disimpulkan bahwa tingkat pengetahuan responden tentang definisi Luka Diabetes di Ruang Wanita Rumah Sakit PTPN II Bangkatan Binjai yang berpengetahuan baik sebanyak 6 orang (60\%), berpengetahuan cukup 2 orang (20\%) dan berpengetahuan kurang 2 orang (20\%).

3) Pencegahan Luka Diabetes

Berdasarkan Tabel 1.5 berdasarkan hasil penelitian dapat disimpulkan bahwa tingkat pengetahuan responden tentang pencegahan luka diabetes yang di Ruang Wanita Rumah Sakit PTPN II Bangkatan Binjai yang berpengetahuan baik sebanyak 5 orang $(50 \%)$, berpengetahuan cukup 4 orang $(40 \%)$ dan berpengetahuan kurang 1 orang $(10 \%)$.

4) Tujuan Perawatan Luka Diabetes

Berdasarkan Tabel 1.6 berdasarkan hasil penelitian dapat disimpulkan bahwa tingkat pengetahuan responden tentang Tujuan Perawatan Luka Diabetes di Ruang Wanita Rumah Sakit PTPN II Bangkatan Binjai yang berpengetahuan baik sebanyak 5 orang $(50 \%)$, berpengetahuan cukup 4 orang $(40 \%)$ dan berpengetahuan kurang 1 orang (10\%).

\section{KESIMPULAN}

Dari hasil penelitian dan pembahasan berdasarkan hasil penelitian terhadap karakteristik responden dan jawaban kuisioner responden tentang Tingkat Pengetahuan Pasien Tentang Perawatan Luka Diabetes di Ruang Wanita Rumah Sakit PTPN II Bangkatan Binjai Tahun 2016. Oleh karena itu penulis menyimpulkan:

1. Penelitian tentang Tingkat Pengetahuan Pasien Tentang Perawatan Luka Diabetes di Ruang Wanita Rumah Sakit PTPN II Bangkatan Binjai Tahun 2016 telah dilaksanakan dengan baik berkat kerjasama peneliti dengan responden.

2. Pengolahan data Tingkat Pengetahuan Pasien tentang Perawatan Luka Diabetes Melitus di Ruang Wanita Rumah Sakit PTPN II Bangkatan Binjai Tahun 2016 berdasarakan tingkat usia 41-50 tahun sebanyak 5 orang (50\%), usia 30-40 sebanyak 2 orang (20\%) dan usia 51-60 sebanyak 3 orang $(30 \%)$.

3. Pengolahan data Tingkat Pengetahuan Pasien tentang Perawatan Luka Diabetes Melitus di Ruang Wanita Rumah Sakit PTPN II Bangkatan Binjai Tahun 2016 berdasarkan pendidikan berpendidikan SMP sebanyak 7 orang $(70 \%)$ dan SMA sebanyak 3 orang (30\%).

4. Berdasarkan hasil Tingkat Pengetahuan Pasien Tentang Perawatan Luka Diabetes di Ruang Wanita Rumah Sakit PTPN II Bangkatan Binjai Tahun 2016 yang di interprestasikan terdapat yang berpengetahuan baik sebanyak 6 orang (60\%), cukup sebanyak 2 orang (20\%) dan kurang sebanyak 2 orang $(20 \%)$.

5. Berdasarkan hasil penelitian dapat disimpulkan bahwa tingkat pengetahuan responden berdasarkan definisi Luka Diabetes di Ruang Wanita Rumah Sakit PTPN II Bangkatan Binjai yang berpengetahuan baik sebanyak 6 orang (60\%), berpengetahuan cukup 2 orang (20\%) dan berpengetahuan kurang 2 orang $(20 \%)$.

6. Berdasarkan hasil penelitian dapat disimpulkan bahwa tingkat pengetahuan responden berdasarkan pencegahan luka diabetes yang di Ruang Wanita Rumah Sakit PTPN II Bangkatan Binjai yang berpengetahuan baik sebanyak 5 orang (50\%), berpengetahuan cukup 4 orang (40\%) dan berpengetahuan kurang 1 orang $(10 \%)$.

7. Berdasarkan hasil penelitian dapat disimpulkan bahwa tingkat pengetahuan responden berdasarkan Tujuan Perawatan Luka Diabetes di Ruang Wanita Rumah Sakit PTPN II Bangkatan Binjai yang berpengetahuan baik sebanyak 5 orang (50\%), berpengetahuan cukup 4 orang (40\%) dan berpengetahuan kurang 1 orang (10\%). 


\section{SARAN}

Dari hasil penelitian yang sudah dijabarkan maka penulis memberi beberapa saran yaitu :

1. Kepada pasien diharapkan mulailah menerapkan pola hidup sehat dari sekarang demi kesehatan dimasa yang akan datang. Salah satu usaha untuk menjaga kesehatan yaitu menjaga kadar gula darah dalam batas normal. Mengatur pola makan yang sehat, seperti sayuran dan buah- buahan, berolahraga teratur, membuang kebisaan buruk seperti merokok, minumn beralkohol adalah halhal penting yang dapat di amalakan dalam menjaga kadar gula dalam batas normal.

2. Diharapkan, pasien mampu mencegah Luka Diabetes dengan pengendalian glukosa darah, penggunaan alas kaki, merawat kuku kaki, perawatan kaki dan senam kaki. Jika sudah terjadi Komplikasi dengan Luka Diabetes, diharapkan pasien mampu melakukan perawatan luka diabetes dengan baik

3. Bagi Rumah Sakit diharapkan dapat menjadi bahan masukan yang diperlukan dalam pelaksanaan praktik pelayanan keperawatan khususnya perawatan luka Diabetes Melitus.

4. Bagi institusi diharapkan dapat menjadi bahan acuan dalam kegiatan proses belajar dan bahan pustaka tentang keperawatan khususnya perawatan luka Diabetes Melitus.

5. Bagi Peneliti diharapkan dapat menjadi Sebagai sarana dan alat untuk menambah pengetahuan dan memperoleh pengalaman khususnya dibidang perawatan luka Diabetes Melitus.
DAFTAR PUSTAKA

Askandar. 2012. Mengenal Lebih Dalam mengenai Diabetes Melitus, Yogyakarta : Nuha Media.

Holt, P. 2013. Asessment and management of patient with diabetic foot ulcers, Jakarta: EGC.

Kedutaan Besar Australia Indonesia. 2013. Mengelola luka diabetes dan tekhnologi mutakhir (http://www.indonesia.embasy.gov.au. Di akses pada 22 Januari 2016).

Maryunani, A. 2013. Perawatan Luka Modern (Modern Woud care), Jakarta: Inmedia.

Nursalam. 2007. Pendidikan dan Perilaku Kesehatan, Jakarta : Salemba Medika.

Notoatmodjo. 2007. Promosi Kesehatan dan Ilmu Perilaku, Jakarta : Rineka Cipta.

Notoatmodjo. 2010. Metodelogi Penelitian, Jakarta : Rineka Cipta.

Persi (Pusat Data dan Informasi). 2011. RI Rangking keempat jumlah penderita Diabetes terbanyak dunia (http:// www. pdpersi.co.id/ content/news. php?mid= 5 diakses tanggal 22Januari 2016).

Rowe, P. 2014. Diabetic Ulcer, emedicine (http:// emedicine. medspace.com/ article diakses 22 januari 2016).

Saad, A. 2013. Wound Bed Preparation For Chronic Diabetic Foot Ulcers. Jakarta : Salemba Medika.

Soegondo. 2013. Buku Ajar Keperawatan Medikal Bedah Brunner \& Suddart Vol 2 ed.8, Jakarta : Balai Penerbit FKUI.

Teguh, S. 2010. Asuhan Keperawatan Diabetes Melitus, Jakarta : Balai Penerbit. 